${ }^{1}$ Gita Indah Budiarti, ${ }^{2}$ Murein Miksa

Mardhia, ${ }^{3}$ Ahmad Azhari

'Program Studi Teknik Kimia, Fakultas

Teknologi Industri,

Universitas Ahmad Dahlan

2,3Program Studi Teknik Informatika,

Fakultas Teknologi Industri,

Universitas A hmad Dahlan

Jalan Ahmad Yani, Kragilan, Tamanan,

Banguntapan, Bantul,

Yogyakarta 55191

Email: gita.indah@che.uad.ac.id

\section{Pengembangan Pangan Lokal Melalui Modifikasi Tepung}

\author{
A L ocal Food D evelopment Through Flour M odification
}

https:/ / doi.org/ 10.18196/ bdr.7261

\begin{abstract}
People with diabetes mellitus in Gunungkidul are increasing. This is caused by excessive consumption of flourbased foods. Communities need to be introduced to alternative food substitutes for flour such as cassava. Besides being able to reduce flour consumption in the community, training and education about non-flour snacks can also increase the income of less productive housewives. The purpose of this activity is to provide education about the dangers of consuming foods containing excessive flour and training in making flour and food from non-wheat alternative ingredients to mothers of Aisyiyah members in the Gunungkidul area. The series of service activities carried out in the form of counseling on food security and healthy food. The second activity was in the form of training in making flour substitute flour and non-flour processed foods. The evaluation phase is in the form of filling out questionnaires by participants. The results of this activity were processed foods made from non-modified flour and improved knowledge and skills of the participants.
\end{abstract}

Keywords: counseling, non-weathed foods, training

\title{
PENDAHULUAN
}

Pimpinan Daerah Aisyiyah (PDA) wilayah Kabupaten Gunungkidul membawahi Pimpinan C abang A isyiyah (PCA) di seluruh Kecamatan di G unungkidul. Salah satunya adalah PCA di Kecamatan Paliyan, Kabupaten Gunungkidul. PCA Kecamatan Paliyan tidak seproduktif PCA yang lain di Kabupaten Gunungkidul. Desa Karangduwet merupakan salah satu desa di Kecamatan Paliyan yang memiliki luas wilayah sebesar $1.744 \mathrm{Ha}$ (BPS Gunungkidul, 2013). Penduduk di desa Karangduwet pada tahun 2018 berjumlah 5.425 jiwa, penduduk laki-laki sebesar 3.304 jiwa dan perempuan 3.380 jiwa. $M$ ata pencaharian penduduk di Karangduwet sebagian besar adalah pada sektor pertanian/ peternakan/ perikanan yaitu 2.159 jiwa. Di Kecamatan Paliyan, jumlah ibu rumah tangga dan pensiunan yang tidak produktif juga tinggi sebesar 579 jiwa (Kependudukan Provinsi Jogja, 2018). Tingginya an gka pen duduk yang kurang produktif tersebut mengakibatkan rendahnya pendapatan perkapita Kecamatan Paliyan. 
Mitra merupakan kelompok Aisyiyah Gunungkidul bidang Majelis Ekonomi dan Ketenagakerjaan (MEK). Divisi ini terdiri atas 35 anggota dari berbagai PCA dengan profesi beragam, dari ibu rumah tangga, petani, PNS, dan lainnya. MEK ini setelah dilatih akan meneruskan pelatihan yang telah diberikan kepada ibu-ibu yanglain terutama di daerah Paliyan.

Konsumsi masyarakat terhadap tepung terigu di Kabupaten Gunungkidul masih tinggi, khususnya Desa Karangduwet. $\mathrm{H}$ al ini dapat dilihat dari kebiasaan masyarakat lokal mengonsumsi makanan kecil (camilan) yang berupa kue dan gorengan. Makanan ini berpotensi menaikkan risiko kadar gula dan membahayakan kesehatan. Nilai konsumsi tepung terigu tiap rumah tangga di G unungkidul mencapai Rp94.731.000.000. M akanan olahan dari tepung terigu yang digemari masyarakat $G$ unungkidul antara lain makanan ringan sebanyak Rp133.431.000.000 dan gorengan sebanyak Rp253.252.000.000 (Subdirektorat Statistik Harga Pedesaan, 2014). Tepung terigu terbuat dari gandum. Produksi gandum dalam negeri belum cukup untuk memenuhi kebutuhan konsumsi dalam negeri, kekurangan kebutuhan gandum dalam negeri yang sangat besar hanya bisa dipenuhi melalui impor (Zulaidah, 2011). Gandum memiliki kandungan berupa protein gluten. Komposisi protein gluten di dalam gandum dapat mencapai $80 \%$ dari total protein dalam gandum. Senyawa gluten tersusun atas dua fraksi, yaitu glutenin dan gliadin yang masing-masing akan men entukan elastisitas serta plastisitas adonan. Sifat elastis dan plastis pada adonan roti tersebut diakibatkan karena terbentuknya "kerangka" seperti jaring dari senyawa glutenin dan gliadin. Adanya jaring tersebut berperan sebagai penangkap gas sehingga adonan roti dapat mengembang (Zulaidah, 2011 dan M irhosseini, et al., 2015).

Gluten dapat meningkatkan kadar gula dalam darah meningkat dan menyebabkan diabetes. Diabetes merupakan penyakit yang menduduki peringkat teratas penyebab kematian setelah penyakit jantung. Penderita diabetes semakin meningkat dan hal ini ditunjukkan dengan revalensi diabetes di atas usia 15 tahun di Provinsi DIY sebesar 15\%, sedangkan di Kabupaten Gunungkidul prevalensinya 2,9\% (Zahroh, 2017). O leh sebab itu, untuk menekan jumlah penderita diabetes di Kabupaten Gunungkidul, khususnya di Kecamatan Paliyan diperlukan bahan pangan alternatif berserat, rendah gluten, sebagai subtitusi gandum pada tepung terigu untuk makanan ringan yang bercita rasa lezat.

Ketela pohon merupakan hasil pangan terbesar di Kecamatan Paliyan. Data Dinas Pertanian tahun 2016 menyatakan produksi ketela pohon sebesar 1.029.196 ton (D inas 
Pertanian DIY, 2018). Ketela pohon adalah pohon tahunan yang hidup di daerah tropis dan subtropis. Ketela pohon ( $\mathrm{M}$ anihot $\mathrm{U}$ tilissima Phol) merupakan jen is tanaman berkayu, beruas, panjang dan tinggi pohonnya bisa mencapai sekitar 3 meter atau lebih. A kar dari ubi kayu bisa mencapai 20-80 cm dan diameternya bisa mencapai 5-10 cm. U kuran diameter dan akar tergantung pada jenis ubi kayu (M astuti, 2010). Kandungan gizi ketela pohon pada Tabel 1 (Zulaidah, 2011). Ketela pohon sudah banyak dikembangkan di Kabupaten Gunungkidul, namun pemanfaatan ketela pohon di Gunungkidul belum dikembangkan. Ketela pohon hanya dijual dengan harga murah.

Tabel 1. Komposisi Pati pada Ketela Pohon

\begin{tabular}{cc}
\hline KOM POSISI & PERSEN BERAT (\%) \\
\hline Karbohidrat & 87,87 \\
Lemak & 0,51 \\
Protein & 1,60 \\
Air & 7,80 \\
Abu & 2,22 \\
\hline
\end{tabular}

Pemberdayaan kepadaibu-ibu Aisyiyah Kabupaten G unungkidul dengan memberikan pelatihan pembuatan makanan ringan berbahan nonterigu serta cara pemasaran nya dapat meningkatkan pendapatan Kecamatan Paliyan khususnya di Karangduwet guna mengurangi kemiskinan. M elalui kerjasama dengan PDA G unungkidul khususnya bidang M ajelis Ekonomi Divisi Ketahanan Pangan, tim PKM mendatangkan narasumber yang telah lama bergerak dalam usaha memajukan ekonomi daerah melalui bahan pangan lokal untuk berbagi pengetahuan dan keterampilan kepada masyarakat untuk meningkatkan produktivitas dan kesejahteraan keluarga. Program ini juga mendukung program pemerintah $\mathrm{G}$ unungkidul dalam hal ketahanan dan keman dirian pangan dengan mengurangi ketergantungan impor tepung terigu dari gandum.

\section{METODE PELAKSANAAN}

Metode yang digunakan pada program ini adalah pelatihan dan penyuluhan. Responden yang dipilih adalah perwakilan dari setiap PCA, terutama PC A Paliyan. Program ini dibagi menjadi beberapa tahapan. D etail tahapan tersebut yaitu :

\section{Tahap Sosialisasi}

Tahap pertama adalah melakukan sosialisasi dan koordinasi terkait waktu pelaksanaan pengabdian masyarakat. 


\section{1}

2. Tahap Kegiatan inti :

a. Penyuluhan tentang makanan sehat dari Dinas Kesehatan Kabupaten G unungkidul Pada kegiatan ini, peserta yang merupakan PDA Kab. Gunungkidul yang terdiri dari perwakilan PCA antara lain, PCA Paliyan, Playen, dsb. Kegiatan ini dilaksanakan pada hari Sabtu tanggal 20 A pril 2019 di Kampung Tani Resto, Wonosari, G unungkidul. Tim pengabdian bekerja sama dengan PDA G unungkidul mendatangkan narasumber dari pakar gizi dan produksi makanan ringan untuk berbagi untuk memberikan penyuluhan mengenai serba-serbi makanan sehat bagi masyarakat. Peserta dapat melakukan diskusi dengan tanya jawab langsung kepada narasumber mengenai topik tersebut

b. Pelatihan mengolah bahan camilan sehat dari ketela pohon dan kentang Pada kegiatan ini, peserta diajak untuk membuat tepung dari ketela pohon dan kentang. Peserta dibagi menjadi lima kelompok. M asing-masing kelompok diberikan satu set alat untuk membuat tepung kentang maupun tepung ketela pohon. Alat yang diberikan yaitu oven, satu set alat masak, dan blender. Tim PKM terlebih dahulu menjelaskan bahan dan fungsi alat-alat yang digunakan. Setelah itu, tim PKM mempraktikkan cara membuat tepung terlebih dahulu, kemudian dilanjutkan oleh peserta. Tim PKM juga mendampingi peserta saat pelatihan. Setelah tepung jadi peserta diajak untuk mengolah salah satu kue yaitu brownis.

3. Tahap evaluasi dilakukan dengan pengisian kuesioner oleh peserta pelatihan. Kuesioner berisi tentang kepuasan peserta mengenai pelaksanaan kegiatan dan peningkatan keterampilan serta pengetahuan peserta setelah mengikuti kegiatan ini.

\section{HASIL DAN PEMBAHASAN}

\section{Penyuluhan Makanan Sehat}

Kegiatan penyuluhan makanan sehat ini menghadirkan narasumber Bapak Agung dari Badan PO M K abupaten G un ungkidul. Kegiatan ini pertama dibuka oleh pimpinan PDA Kabupaten Gunungkidul dan Ketua Majelis Ekonomi divisi ketahanan pangan. $M$ ateri yang disampaikan mengenai keamanan pangan dan cara memilih pangan sehat. Foto kegiatan disajikan pada $\mathrm{G}$ ambar 3. Keamanan pangan merupakan hal yang san gat penting karena makanan yang kita makan akan berpengaruh terhadap metabolisme tubuh. Para ibu merupakan filter untuk keluarganya, terutama masalah makanan. M anfaat dari penyuluhan ini dapat menambah pengetahuan peserta mengenai makanan sehat dan tidak sehat dan bagaimana mengolah makanan secara higienis. M akanan yang tidak sehat adalah makanan yang mengandung kolesterol dan gula yang berlebihan. 


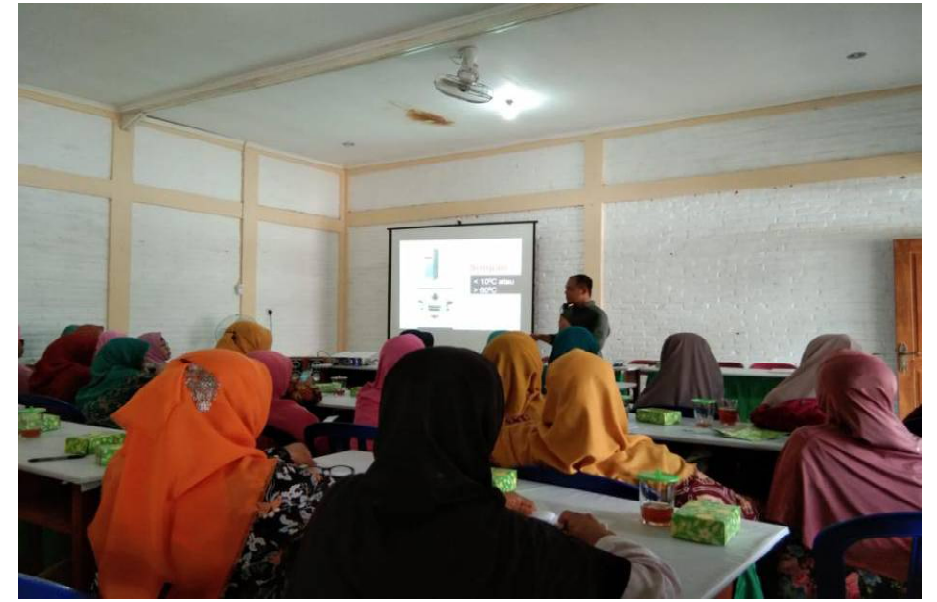

Gambar 1. Penyuluhan Keamanan Pangan oleh Badan POM Kabupaten Gunungkidul

\section{Pelatihan mengolah bahan camilan sehat}

Pelatihan diawali dengan penjelasan dari tim PKM mengenai bahan baku yaitu ketela pohon dan kentang (Gambar 4). Penjelasan meliputi bahaya penggunaan terigu yang mengandung gluten, macam-macam bahan lokal yang dapat digunakan untuk subtitusi terigu dan pengertian tepung modifikasi. Tepung modifikasi merupakan tepung yang sudah diubah sifatnya menjadi mirip dengan terigu. Tujuan modifikasi ini adalah untuk mensubtitusi terigu. Teknik modifikasi ada berbagai macam yaitu fisika dan kimia (Zulaidah, 2011). Pada kegiatan kali ini, modifikasi yang digunakan adalah modifikasi secara kimia, yaitu menggunakan fermipan utuk ketela pohon dan hydrogen rich water untuk kentang. Tahap selanjutnya adalah pembuatan tepung modifikasi ketela pohon dan kentang. Ketela pohon dan kentang dipilih karena ketersediaannya yang melimpah dan kandungan glutennya rendah (Zulaidah, 2011 dan Mirhosseini, et al., 2015). Berikutnya, tahap pembuatan tepung ketela pohon. Pertama, pengupasan dilanjutkan pengirisan ketela pohon (G ambar 5). Tahap selanjutnya adalah perendaman menggunakan fermipan. Setelah diredam, potongan ketela pohon (mokaf) akan terpisah dengan tapioka. Mokaf yang sudah direndam kemudian dicuci bersih dan dikeringkan menggunakan oven. Setelah kering, potongan mokaf kering dihancurkan menggunakan blender kemudian diayak. Tahap yang hampir sama juga dilakukan untuk pembuatan tepung kentang. Kentang tidak direndam dengan fermipan tetapi menggunakan hydrogen rich water. U ntuk menghemat biaya produksi hydrogen rich water dapat diganti menggunakan air biasa. Setelah itu, tim PKM mempraktikkan pembuatan kue brownis, sebagai contoh camilan (Gambar 6), peserta dapat membuat camilan yang lain sesuai selera. Peserta dibagi menjadi lima kelompok dan masing-masing diberi alat satu set yang berisi oven, 
blender, dan alat kupas. Peserta diminta mempraktikkan kembali pembuatan tepung dan brownis. H asil dari program ini peserta telah mampu mempraktikkan seluruh tahap. $\mathrm{N}$ amun, karena waktu pengeringan terlalu lama kurang lebih 10 jam, tahapan dihentikan sampai mokaf masuk ke dalam oven. Pembuatan makanan olahan menggunakan tepung hasil uji coba tim sebelumnya. Peserta juga mampu membuat makanan olahan brownis. Diharapkan peserta dapat mengulangi semua proses secara mandiri.

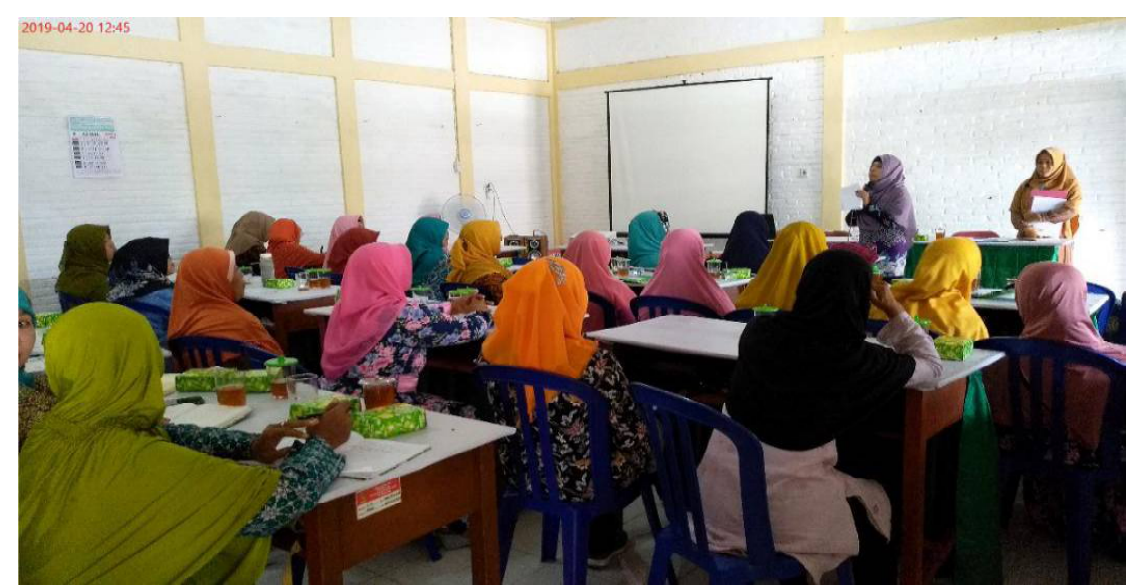

Gambar 2. Penjelasan Materi Pembuatan Tepung oleh Tim PKM

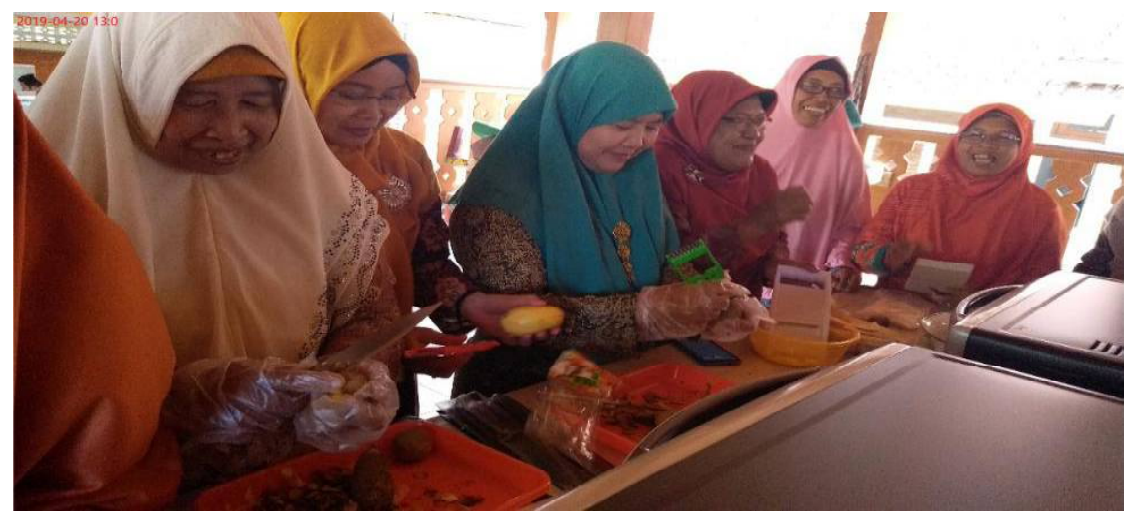

Gambar 3. Proses Pelatihan Pembuatan Tepung Mokaf

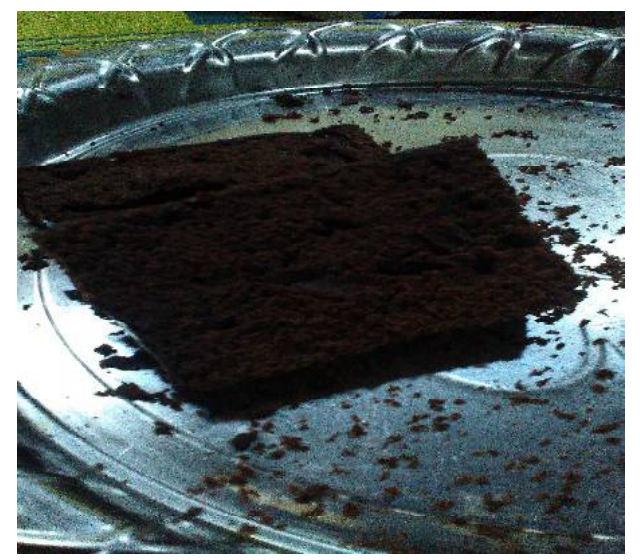

Gambar 4. Brownis Hasil Praktik 


\section{Tahap Evaluasi}

Tahap terakhir adalah evaluasi. Evaluasi berupa peserta diminta untuk mengisi kuesioner. D ari hasil kuesioner yang dikumpulkan diperoleh hasil yang disajikan pada Gambar 7.

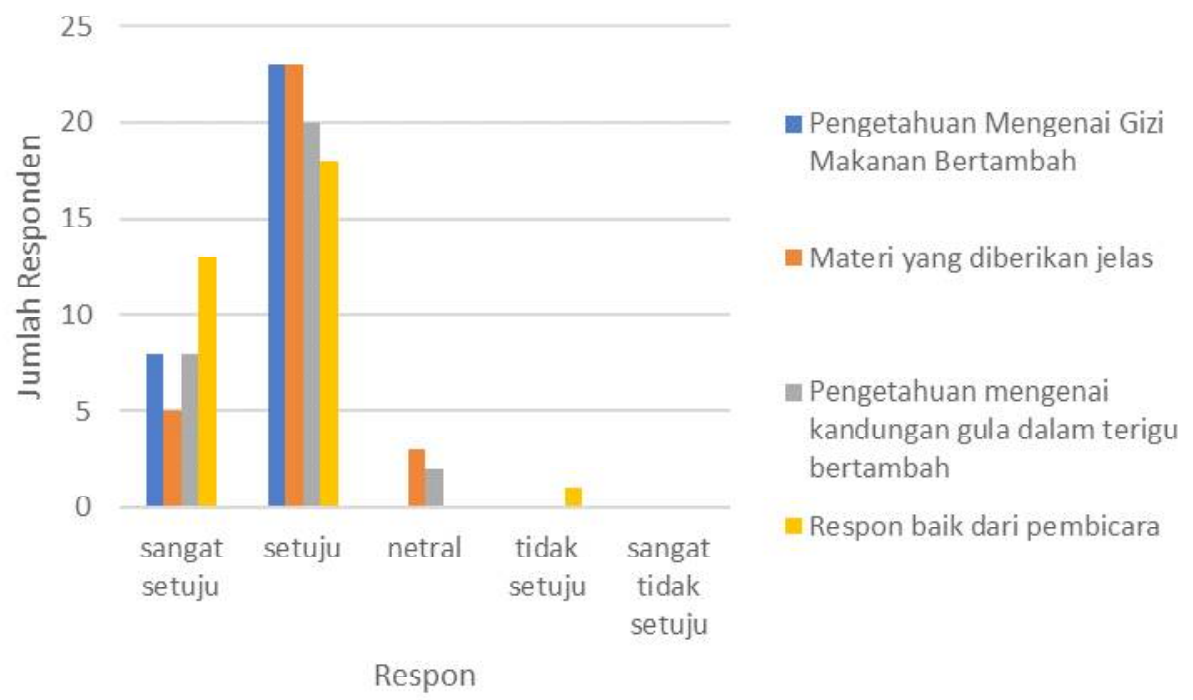

Grafik 1. Data Evaluasi Pengetahuan Peserta

Dari data di atas terdapat empat pertanyaan yaitu tentang pengetahuan yang bertambah, yaitu pengetahuan mengenai gizi dalam makanan dan bahaya gula dalam terigu dan tentang pemateri serta materi yang dijelaskan. Sebagian besar, dari total 31 responden, 23 responden menyatakan pengetahuannya mengenai gizi dalam makanan bertambah. Sebanyak 23 responden menyatakan materi yang diberikan jelas. Pada pertanyaan mengenai pengetahuan peserta kandungan gula dalam terigu bertambah, sebanyak 20 pesertayang menyatakan pengetahuannya bertambah. Respon dari pembicara baik, hal ini dibuktikan dengan 18 peserta menyatakan puas atau setuju dan 13 lainnya sangat setuju. $\mathrm{Hal}$ ini menunjukkan penyuluhan berhasil meningkatkan pengetahuan peserta, Peserta juga memberi masukan kepada tim PKM agar kegiatan ini dapat ditindaklanjuti dengan pelatihan berikutnya. M ereka menyatakan bersedia mengikuti apabila ada acara berikutnya. $\mathrm{Hal}$ ini menunjukkan antusiasme peserta mengikuti kegiatan.

Peningkatan keterampilan peserta setelah mengikuti pelatihan dapat dilihat pada Gambar 8. Data tersebut menunjukkan bahwa $44 \%$ peserta sangat setuju apabila keterampilan mereka bertambah. Indikator lain yaitu peserta berhasil mempraktikkan cara modifikasi tepung serta membuat makanan olahan contohnya brownis, dengan baik. 


\section{5}

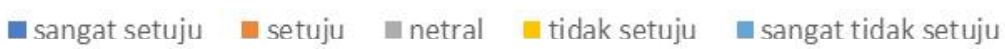

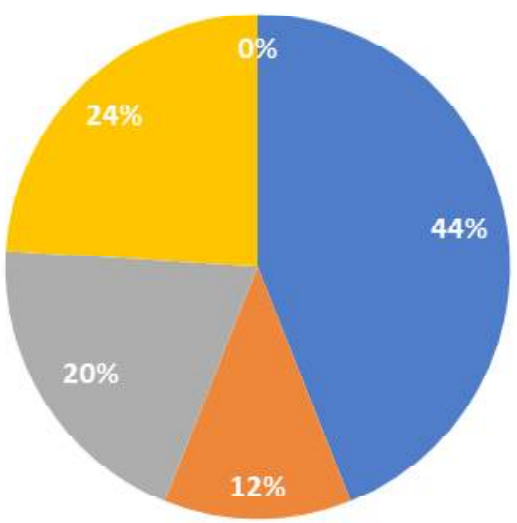

Diagram 1. Pernyataan Peserta Mengenai Ketrampilan yang Bertambah

\section{SIM PULAN}

Berdasarkan kegiatan program kemitraan masyarakat yang telah dilakukan dapat disimpulkan bahwa program ini dapat meningkatkan pengetahuan peserta dan keterampilan peserta mengenai makanan olahan sehat yang terbuat dari bahan pangan lokal nonterigu. Keterampilan yang diperoleh diharapkan dapat menjadi bekal untuk menambah penghasilan peserta menjadi masyarakat yang lebih berdaya.

\section{UCAPAN TERIMA KASIH}

Kegiatan ini didanai oleh Kementrian Riset dan Teknologi dalam Program Kemitraan M asyarakat den gan nomor kontrak L1/001/ C .6/ III/ 2019 dan DIPA-042.06-1.401516/ 2019. Terima kasih kepada mitra Pimpinan Daerah Aisyiyah Gunungkidul khususnya Majelis Ekonomi dan Ketenagakerjaan. Terimakasih kepada Lembaga Penelitian dan Pengabdian M asyarakat U niversitas A hmad Dahlan yang telah membantu penyelenggaraan program ini.

\section{DAFTAR PUSTAKA}

BPS Gunungkidul. 2013. Kecamatan Paliyan dalam

Angka 2013. http://

bappeda.gunungkidulkab.go.id/publikasi/kda/

2013/paliyan.pdf [diakses pada tanggal 20

Agustus 2018]

Dinas Pertanian DIY. 2018. Data Hasil Pertanian

Kabupaten Gunungkidul Bulan September-

Desember 2016. http://distan.jogjaprov.go.id/ statistik-tanaman-pangan [diakses tanggal 20 Agustus 2018].

Kependudukan Provinsi Jogja. 2018. Jumlah Penduduk Kecamatan Paliyan. http://kependudukan.jogjaprov. go. id/olah. php?module= statistik\&periode $=5 \&$ jenisdata $=$ penduduk\&berdasarka$\mathrm{n}=$ jumlahpenduduk\&prop $=34 \& k a b=03 \& k e c=05$ [diakses pada tanggal 20 Agustus 2018] 
Mastuti, E., Setyawardhani, D.A. 2010. "Pengaruh Variasi Temperatur dan Konsentrasi Katalis pada Kinetika Reaksi Hidrolisis Tepung kulit Ketela Pohon". Ekuilibrium, 9(1), pp.23-27.

Mirhosseini, H., Farhana, N., Rashid, A., Tabatabaee, B., Whye, K., Kazemi, M. 2015. Effect of Partial Replacement of Corn Flour with Durian Seed Flour and Pumpkin Flour on Cooking Yield, Texture Properties and Sensory Attributes of Gluten Free Pasta. LWT - Food Science and Technology, 63, pp. 184-190.

Subdirektorat Statistik Harga Pedesaan. 2014.

Diagram Timbang Nilai Tukar Petani. Badan Pusat Statistik. www.bps.go.id[diakses pada tanggal 20 Agustus 2018].

Zahroh, S.F. 2017. "Hubungan Antara Asupan Serat Dan Aktivitas Fisik Dengan Kadar Glukosa Darah Puasa Karyawan Puskesmas Rongkop Gunungkidul". Kementrian Kesehatan Republik Indonesia Badan Pengembangan Dan Pemberdayaan SDM Kesehatan.

Zulaidah, Agustien. 2011. “Modifikasi Ubi Kayu Secara Biologi Menggunakan Starter Bimo-CF Menjadi Tepung Termodifikasi Pengganti Gandum". Universitas Diponegoro Semarang. 